\title{
Aspartate buffer and divalent metal ions affect oxytocin in aqueous solution and protect it from degradation
}

\author{
Christina Avanti ${ }^{\mathrm{a}, \mathrm{b}, *, 1}$, Nur Alia Oktaviani $\mathrm{c}^{\mathrm{c}, 1}$, Wouter L.J. Hinrichs ${ }^{\mathrm{a}}$, \\ Henderik W. Frijlink ${ }^{\mathrm{a}}$, Frans A.A. Mulder ${ }^{\mathrm{c}, \mathrm{d}}$ \\ a Department of Pharmaceutical Technology and Biopharmacy, University of Groningen, Antonius Deusinglaan 1, 9713 AV, Groningen, The Netherlands \\ ${ }^{b}$ Department of Pharmaceutics, Faculty of Pharmacy, University of Surabaya (Ubaya), Surabaya, Indonesia \\ c Groningen Biomolecular Sciences and Biotechnology Institute, University of Groningen, Nijenborgh 4, 9747 AG, Groningen, The Netherlands \\ d Department of Chemistry and Interdisciplinary Nanoscience Center iNANO, University of Aarhus, Langelandsgade 140, DK-8000 Aarhus C, Denmark
}

\section{A R T I C L E I N F O}

\section{Article history:}

Received 25 October 2012

Received in revised form 22 January 2013

Accepted 24 January 2013

Available online 1 February 2013

\section{Keywords:}

Oxytocin

Conformation

Aspartate buffer

Aqueous solution

Divalent metal ions

NMR

\begin{abstract}
A B S T R A C T
Oxytocin is a peptide drug used to induce labor and prevent bleeding after childbirth. Due to its instability, transport and storage of oxytocin formulations under tropical conditions is problematic. In a previous study, we have found that the stability of oxytocin in aspartate buffered formulation is improved by the addition of divalent metal ions (unpublished results). The stabilizing effect of $\mathrm{Zn}^{2+}$ was by far superior compared to that of $\mathrm{Mg}^{2+}$. In addition, it was found that stabilization correlated well with the ability of the divalent metal ions to interact with oxytocin in aspartate buffer. Furthermore, LC-MS (MS) measurements indicated that the combination of aspartate buffer and $\mathrm{Zn}^{2+}$ in particular suppressed intermolecular degradation reactions near the $\mathrm{Cys}^{1,6}$ disulfide bridge. These results lead to the hypothesis that in aspartate buffer, $\mathrm{Zn}^{2+}$ changes the conformation of oxytocin in such a way that the Cys ${ }^{1,6}$ disulfide bridge is shielded from its environment thereby suppressing intermolecular reactions involving this region of the molecule. To verify this hypothesis, we investigate here the conformation of oxytocin in aspartate buffer in the presence of $\mathrm{Mg}^{2+}$ or $\mathrm{Zn}^{2+}$, using 2D NOESY, TOCSY, ${ }^{1} \mathrm{H}_{-}{ }^{13} \mathrm{C}$ HSQC and ${ }^{1} \mathrm{H}-{ }^{15} \mathrm{~N}$ HSQC NMR spectroscopy. Almost all ${ }^{1} \mathrm{H},{ }^{13} \mathrm{C}$ and ${ }^{15} \mathrm{~N}$ resonances of oxytocin could be assigned using HSQC spectroscopy, without the need for ${ }^{13} \mathrm{C}$ or ${ }^{15} \mathrm{~N}$ enrichment. ${ }^{1} \mathrm{H}-{ }^{13} \mathrm{C}$ and ${ }^{1} \mathrm{H}-{ }^{15} \mathrm{~N}$ HSQC spectra showed that aspartate buffer alone induces minor changes in oxytocin in $\mathrm{D}_{2} \mathrm{O}$, with the largest chemical shift changes observed for $\mathrm{Cys}^{1} . \mathrm{Zn}^{2+}$ causes more extensive changes in oxytocin in aqueous solution than $\mathrm{Mg}^{2+}$. Our findings suggest that the carboxylate group of aspartate neutralizes the positive charge of the $\mathrm{N}$-terminus of $\mathrm{Cys}^{1}$, allowing the interactions with $\mathrm{Zn}^{2+}$ to become more favorable. These interactions may explain the protection of the disulfide bridge against intermolecular reactions that lead to dimerization.
\end{abstract}

\section{Introduction}

Oxytocin is a nonapeptide hormone secreted by the posterior lobe of the pituitary gland, and is involved in the control of labor and bleeding cessation after child birth (Maughan et al., 2006). The peptide consists of nine amino acids (Cys-Tyr-Ile-Gln-Asn-Cys-Pro-Leu-Gly- $\mathrm{NH}_{2}$ ) with an internal disulfide bridge, and an amidated C-terminus (du Vigneaud et al., 1953). Oxytocin is the preferred drug to prevent postpartum hemorrhage and is commonly formulated in aqueous solution for

\footnotetext{
* Corresponding author. Present address: Department of Pharmaceutics, Faculty of Pharmacy, University of Surabaya (Ubaya), Raya Kalirungkut, Surabaya 60293, Indonesia. Tel.: +62 31 2981110; fax: +62 312981111 .

E-mail addresses: c.avanti@rug.nl, c_avanti@staff.ubaya.ac.id (C. Avanti).

1 Equally contributed first author.
}

parenteral administration (Gard et al., 2002). The instability of oxytocin in aqueous solution under harsh circumstances, particularly under tropical conditions, presents a significant challenge to pharmaceutical scientists (Hawe et al., 2009). The instability of oxytocin in aqueous solution has been reported in several studies (Hogerzeil et al., 1993; Trissel et al., 2006). It has been found that the degradation rate strongly depends on the $\mathrm{pH}$ of the formulation, with the highest stability reported at pH 4.5 (Hawe et al., 2009). Several studies have been aimed at the improvement of the stability of oxytocin in aqueous solution (Avanti et al., 2011; Hawe et al., 2009). The most recent finding is that the use of divalent metal ions, in combination with certain buffers, strongly increases the stability of oxytocin in aqueous solution (Avanti et al., 2012).

Previously, we have shown that $\mathrm{Zn}^{2+}$ in combination with aspartate buffer strongly stabilizes oxytocin in aqueous solutions, whereas $\mathrm{Ca}^{2+}$ and $\mathrm{Mg}^{2+}$ only have minor effects. The stabilization 
Table 1

Information about the NMR experiments.

\begin{tabular}{|c|c|c|c|c|c|c|c|}
\hline Experiment & Correlations provided & $\begin{array}{l}\text { Number } \\
\text { of scans }\end{array}$ & Nuclei & $\begin{array}{l}\text { Spectral } \\
\text { width }(\mathrm{Hz})\end{array}$ & $\begin{array}{l}\text { Carrier } \\
\text { (ppm) }\end{array}$ & $\begin{array}{l}\text { Maximum evolution } \\
\text { time (ms) }\end{array}$ & Reference \\
\hline $2 \mathrm{D}{ }^{15} \mathrm{~N}-{ }^{1} \mathrm{H}$ HSQC & $\begin{array}{l}{ }^{15} \mathrm{~N} \text { and }{ }^{1} \mathrm{H} \text { separated } \\
\text { by one bond }\left(\mathrm{N}^{\mathrm{H}}-\mathrm{H}^{\mathrm{N}}\right. \\
\mathrm{N} \varepsilon-\mathrm{H} \varepsilon \text { for } \mathrm{Gln}, \mathrm{N} \delta-\mathrm{H} \delta \\
\text { for Asn, } \mathrm{N}-\mathrm{H} \text { for amide } \\
\left.\text { of } \mathrm{Gly}^{9}\right)\end{array}$ & 512 & $\begin{array}{l}{ }^{15} \mathrm{~N} \\
{ }^{1} \mathrm{H}\end{array}$ & $\begin{array}{l}1944 \\
8000\end{array}$ & $\begin{array}{l}120.39 \\
5.03\end{array}$ & $\begin{array}{l}20.5 \\
85\end{array}$ & Kay et al., 1992; Mulder et al., 2011 \\
\hline $2 \mathrm{D}{ }^{13} \mathrm{C}-{ }^{1} \mathrm{H}$ HSQC & $\begin{array}{l}{ }^{13} \mathrm{C} \text { and }{ }^{1} \mathrm{H} \text { separated } \\
\text { by one bond }(\mathrm{H} \alpha-\mathrm{C} \alpha \text {, } \\
\mathrm{H} \beta-\mathrm{C} \beta, \mathrm{H} \gamma-\mathrm{C} \gamma, \text { etc. })\end{array}$ & 40 & ${ }^{13} \mathrm{C}$ & $\begin{array}{l}8000 \\
8000\end{array}$ & $\begin{array}{l}48.191 \\
5.04\end{array}$ & $\begin{array}{l}16 \\
100\end{array}$ & Kay et al., 1992; John et al., 1992 \\
\hline $2 \mathrm{D}^{1} \mathrm{H}-{ }^{1} \mathrm{H}$ TOCSY & $\begin{array}{l}\text { Correlates all protons } \\
\text { in a J-coupled spin } \\
\text { system }\end{array}$ & 20 & $\begin{array}{l}{ }^{1} \mathrm{H} \\
{ }^{1} \mathrm{H}\end{array}$ & $\begin{array}{l}8000 \\
8000\end{array}$ & $\begin{array}{l}5.04 \\
5.04\end{array}$ & $\begin{array}{l}16 \\
85\end{array}$ & Davis and Bax, 1985 \\
\hline $2 \mathrm{D}^{1} \mathrm{H}-{ }^{1} \mathrm{H}$ NOESY & $\begin{array}{l}\text { Correlates all protons } \\
\text { which are close in } \\
\text { space }(<0.5 \mathrm{~nm})\end{array}$ & 16 & $\begin{array}{l}{ }^{1} \mathrm{H} \\
{ }^{1} \mathrm{H}\end{array}$ & $\begin{array}{l}8000 \\
8000\end{array}$ & $\begin{array}{l}5.04 \\
5.04\end{array}$ & $\begin{array}{l}25 \\
160\end{array}$ & Boyd et al., 1984 \\
\hline $1 \mathrm{D}{ }^{1} \mathrm{H}$ & & 128 & ${ }^{1} \mathrm{H}$ & 8000 & 5.04 & 2000 & \\
\hline
\end{tabular}

occurred as a result of complex formation of $\mathrm{Zn}^{2+}$ ions and aspartate with oxytocin, which suppressed dimerization by protecting the Cys $^{1,6}$ disulfide bridge. In line with those results, ITC data demonstrate that, among the tested divalent metal ions $\left(\mathrm{Zn}^{2+}, \mathrm{Ca}^{2+}\right.$, and $\mathrm{Mg}^{2+}$ ), only $\mathrm{Zn}^{2+}$ is able to strongly interact with oxytocin in the formulation conditions (unpublished results). These results lead to the hypothesis that $\mathrm{Zn}^{2+}$ induces a conformational change, thereby stabilizing oxytocin in aspartate buffer. Aspartic acid is one of the non-essential amino acids that is normally synthesized in the body. It consists of two carboxylate groups with $\mathrm{pKa}_{1}$ and $\mathrm{pKa}_{2}$ of 2.1 and 3.9, and one amine group ( $\mathrm{pKa}_{3}$ of 9.8). Aspartate is a commonly used buffer in parenteral products approved by the FDA for formulation purposes (Jurgens et al., 1982). The aim of this study was to investigate the conformation of oxytocin in aspartate buffer in the presence of divalent metal ions $\left(\mathrm{Zn}^{2+}\right.$ and $\left.\mathrm{Mg}^{2+}\right)$ by using two-dimensional (2D) Nuclear Magnetic Resonance (NMR) spectroscopy.

Nuclear Magnetic Resonance spectroscopy is the most suited technique to study the conformational details of proteins or peptides in solutions. Several one-dimensional NMR studies of oxytocin and vasopressin analogs have previously been published, studying the peptide hormones in various solvents, including deuterated dimethylsulfoxide (Sikorska et al., 2006; Glickson et al., 1976; Johnson et al., 1969), deuterated trifuoroethanol (TFE) (Ananthanarayanan et al., 1996; Rholam et al., 1990), and aqueous solutions (Glickson et al., 1976; Sikorska and RodziewiczMotowidlo, 2008; Smith et al., 1973). Since resonance overlap is much reduced in 2D NMR spectra in comparison with onedimensional NMR, we use here 2D NMR spectroscopy. In addition, natural abundance 2D HSQC spectroscopy provides access to backbone ${ }^{13} \mathrm{C}$ and ${ }^{15} \mathrm{~N}$ chemical shifts that are highly sensitive reporters of peptide conformation.

Oxytocin solutions are commonly formulated at a concentration of $5 \mathrm{IE} / \mathrm{mL}$ which corresponds to approximately $0.01 \mathrm{mM}$. The concentration used in this study $(10 \mathrm{mM})$ was higher, since it enables NMR measurements without ${ }^{13} \mathrm{C}$ or ${ }^{15} \mathrm{~N}$ enrichment, relying only on the low natural abundance of these isotopes.

A complete NMR analysis of oxytocin in phosphate buffer has been reported (Ohno et al., 2010). However, no reports are available on the ${ }^{1} \mathrm{H},{ }^{13} \mathrm{C}$, and ${ }^{15} \mathrm{~N}$ resonance assignments of oxytocin in aspartate buffer in the absence and presence of divalent metal ions. In this study, we used 1D and 2D NMR spectroscopy to investigate the conformation of oxytocin in the presence of $\mathrm{Zn}^{2+}$ or $\mathrm{Mg}^{2+}$ in aspartate buffer at $\mathrm{pH} 4.5$.

\section{Materials and methods}

\subsection{Chemicals and reagents}

Oxytocin monoacetate powder (Diosynth. Oss, The Netherlands) was kindly provided by MSD, Oss, The Netherlands. Deuterium oxide $\left(\mathrm{D}_{2} \mathrm{O}\right.$, isotopic purity 99.9 atom \% D) containing $0.75 \%$ TSP (3-(trimethylsilyl) propionic-2,2,3,3,-d4 acid, sodium salt) was purchased from Aldrich, Steinheim, Germany and deuterated L-aspartic acid-2,3,3-d3 was purchased from Medical Isotope, Inc, NH. Zinc chloride was purchased from Fluka, Steinheim, Germany. All reagents used for the NMR experiments were of analytical grade (purity $>99 \%$ ), and were used without further purification.

\subsection{Sample preparation}

Two different types of NMR samples were prepared with the following compositions:

1. Samples used for $2 \mathrm{D}{ }^{13} \mathrm{C}-{ }^{1} \mathrm{H}$ HSQC NMR10 mM oxytocin (OT) in $10 \mathrm{mM}$ deuterated aspartate buffer $(\mathrm{pH} 4.5)$ in $\mathrm{D}_{2} \mathrm{O}$ containing $0.75 \%$ TSP in the absence (OT-AP) and presence of $100 \mathrm{mM}$ $\mathrm{ZnCl}_{2}$ (OT-AP-Zn) or $100 \mathrm{mM} \mathrm{MgCl}_{2}$ (OT-AP-Mg). The reference solution was oxytocin in $\mathrm{D}_{2} \mathrm{O}$.

2. Samples used for $1 \mathrm{D}^{1} \mathrm{H}$ NMR, $2 \mathrm{D}{ }^{15} \mathrm{~N}-{ }^{1} \mathrm{H}$ HSQC, ${ }^{1} \mathrm{H}-{ }^{1} \mathrm{H}$ TOCSY, and ${ }^{1} \mathrm{H}-{ }^{1} \mathrm{H}$ NOESY. $10 \mathrm{mM}$ oxytocin in $10 \mathrm{mM}$ aspartate buffer ( $\mathrm{pH} 4.5$ ) in $90 \% / 10 \%(\mathrm{v} / \mathrm{v}) \mathrm{H}_{2} \mathrm{O} / \mathrm{D}_{2} \mathrm{O}$ containing $0.75 \%$ TSP in the absence and presence of $100 \mathrm{mM} \mathrm{ZnCl}_{2}$ or $100 \mathrm{mM} \mathrm{MgCl}_{2}$. The reference solution was oxytocin in a $90 \% / 10 \%(v / v) \mathrm{H}_{2} \mathrm{O} / \mathrm{D}_{2} \mathrm{O}$.

\subsection{NMR spectroscopy}

NMR Spectra were recorded using a Varian Unity INOVA $600 \mathrm{MHz}$ NMR spectrometer equipped with pulsed field-gradient probes. The spectra were recorded at $278 \mathrm{~K}$, processed using NMRPipe (Delaglio et al., 1995) and analyzed using Sparky (Goddard and Kneller, 2003). ${ }^{3} \mathrm{~J}_{\mathrm{HNH} \alpha}$ coupling constants were determined by recording $1 \mathrm{D}{ }^{1} \mathrm{H}$ NMR spectra. All information about the NMR measurements is summarized in Table 1 . TSP was used as an internal standard having a chemical shift $(\delta)$ of $0.0 \mathrm{ppm}$. Chemical shift referencing for ${ }^{13} \mathrm{C}$ and ${ }^{15} \mathrm{~N}$ was done following the IUPAC recommendations of Markley et al. (1998) (for indirect referencing). 

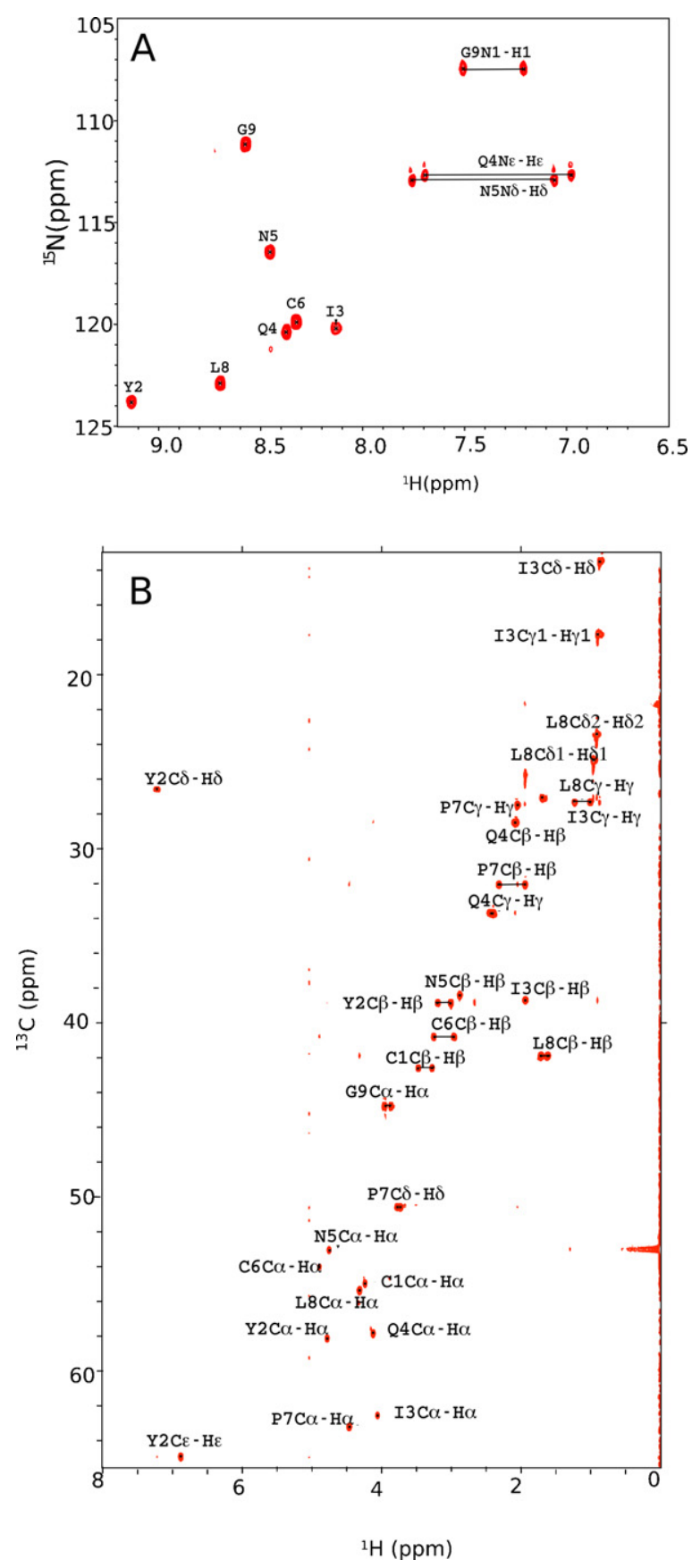

Fig. 1. 2D NMR spectra of oxytocin in aspartate buffer. (A) ${ }^{15} \mathrm{~N}-{ }^{1} \mathrm{H}$ HSQC spectrum, which shows the correlation between amide protons and amide nitrogens in the backbone of the peptide. The correlation between amide protons and amide nitrogens in the side chain of $\mathrm{Gln}^{4}, \mathrm{Asn}^{5}$ are indicated, as well as the $\mathrm{C}$ terminal $\mathrm{Gly}^{9}$ (which has a carboxy-amide group instead of a regular carboxylate, marked $\mathrm{N} 1-\mathrm{H} 11$ and N1-H12); (B) ${ }^{13} \mathrm{C}-{ }^{1} \mathrm{H}$ HSQC spectrum, showing correlations between side chain carbons and their attached protons. The $\operatorname{Tyr}^{2} \mathrm{C} \delta$ and $\mathrm{C} \varepsilon$ signals are aliased (i.e. folded in) in this spectrum. The true $\operatorname{Tyr}^{2} \mathrm{C} \delta$ and $\mathrm{C} \varepsilon$ chemical shifts are 132.69 and $117.95 \mathrm{ppm}$, respectively.

\section{Results}

\subsection{Assignment and data deposition of backbone and aliphatic} side chain resonances of oxytocin in aspartic acid buffer

The assignment of proton, carbon-13 and nitrogen-15 resonance frequencies was accomplished using $2 \mathrm{D}{ }^{13} \mathrm{C}-{ }^{1} \mathrm{H}$ HSQC (Kay et al., 1992; John et al., 1992), ${ }^{15} \mathrm{~N}-{ }^{1} \mathrm{H}$ HSQC (Kay et al., 1992; Mulder

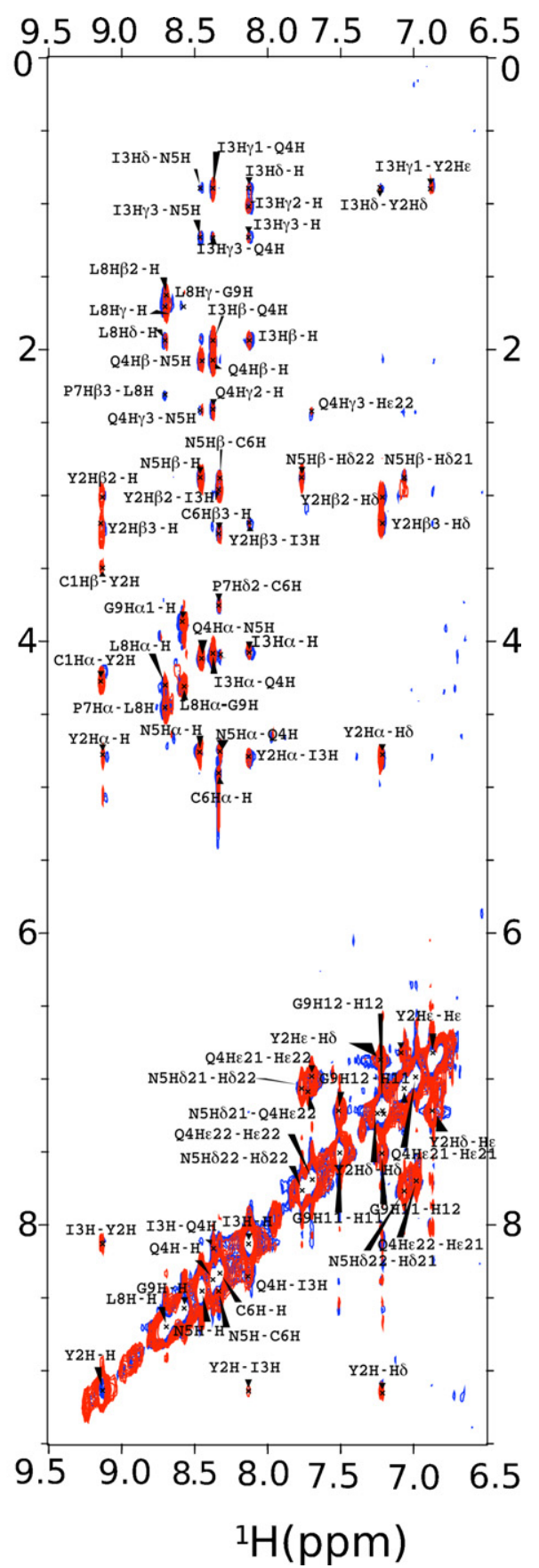

Fig. 2. Overlay of the $2 \mathrm{D}{ }^{1} \mathrm{H}-{ }^{1} \mathrm{H}$ NOESY spectrum of oxytocin in aspartate buffer in the absence and presence of $\mathrm{Zn}^{2+}$.

et al., 2011) and ${ }^{1} \mathrm{H}-{ }^{1} \mathrm{H}$ TOCSY (Davis and Bax, 1985) NMR data. Since the peptide consists of only 9 amino acids, the assignment of ${ }^{13} \mathrm{C}-{ }^{1} \mathrm{H}$ HSQC spectra can be easily achieved based on the uniqueness of carbon and proton resonance of each amino acid (Cavanagh et al., 2006), To avoid disturbance of $\mathrm{H} \alpha$ signals by the strong signal of $\mathrm{H}_{2} \mathrm{O}$ protons in ${ }^{13} \mathrm{C}-{ }^{1} \mathrm{H}$ HSQC experiments, $\mathrm{D}_{2} \mathrm{O}$ was chosen as solvent. No attempt was made to correct for the small isotope shift arising from the backbone amide deuteron.

Amide proton and amide nitrogen resonances in the ${ }^{15} \mathrm{~N}-{ }^{1} \mathrm{H}$ HSQC were assigned by means of ${ }^{1} \mathrm{H}-{ }^{1} \mathrm{H}$ correlations visible in a ${ }^{1} \mathrm{H}-{ }^{1} \mathrm{H}$ TOCSY spectrum. Fig. 1 summarizes the assignment of most of the oxytocin resonances. All peaks observed in ${ }^{1} \mathrm{H}-{ }^{15} \mathrm{~N}(\mathrm{~A})$ and ${ }^{1} \mathrm{H}-{ }^{13} \mathrm{C}$ HSQC spectra (B) are annotated with the one letter amino acid symbol and its position in the sequence. 


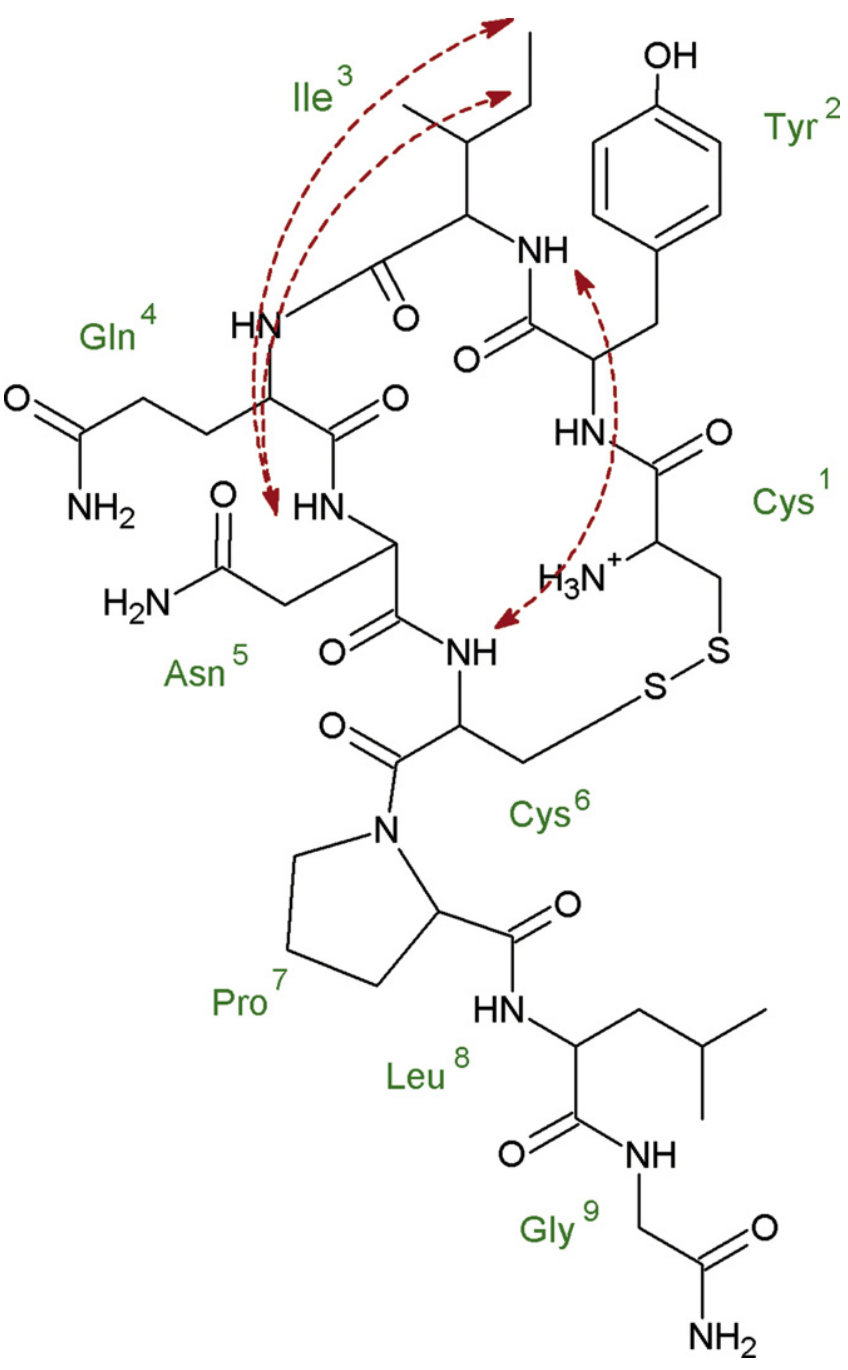

Fig. 3. Summary of short non-trivial distances observed in the $2 \mathrm{D}{ }^{1} \mathrm{H}-{ }^{1} \mathrm{H}$ NOESY spectrum of oxytocin in aspartate buffer.

\subsection{NOE analysis}

To obtain information about pairs of protons which are close in space, 2D ${ }^{1} \mathrm{H}-{ }^{1} \mathrm{H}$ NOESY (Boyd et al., 1984) spectra were recorded for oxytocin in aspartate buffer in the absence and in the presence of $\mathrm{Zn}^{2+}$. From the NOESY spectrum (Fig. 2), it was found that in aspartate buffer residue $\mathrm{Ile}^{3}$ is close to $\mathrm{Cys}^{6}$ and to $\mathrm{Asn}^{5}$. A virtually identical NOESY spectrum was obtained in the presence of $\mathrm{Zn}^{2+}$ (see Supporting information). The short distances from NOESY experiments are schematically presented in Fig. 3.

\subsection{Chemical shift difference $(\Delta \delta)$}

The chemical shift differences induced by divalent metal ions upon complexation with oxytocin in aspartate buffer were analyzed to get information about which residues are involved in binding of the divalent metal ions to oxytocin and to learn about the extent of the perturbation caused by these ions.

\subsubsection{Influence of aspartate buffer on the conformation of oxytocin in water}

Aspartate buffer is one of the buffers known to stabilize oxytocin if divalent metal ions are present in the liquid formulation. The effects of $\mathrm{Zn}^{2+}$ and $\mathrm{Mg}^{2+}$ ions on the $\mathrm{C} \alpha$ and $\mathrm{H} \alpha$ chemical shifts of oxytocin in the presence of aspartate are displayed in Fig. 4. To investigate the influence of aspartate buffer on the conformation of oxytocin, the chemical shift $(\delta)$ of $\mathrm{C} \alpha$ and $\mathrm{H} \alpha$ backbone resonances of oxytocin in deuterated aspartate buffer was compared with the chemical shift of $\mathrm{C} \alpha$ and $\mathrm{H} \alpha$ resonances of oxytocin in $\mathrm{D}_{2} \mathrm{O}$. The difference between those chemical shifts was expressed as chemical shift difference $(\Delta \delta)$ in ppm.

Fig. 5A shows that aspartate buffer induces minor chemical shift changes for oxytocin in $\mathrm{D}_{2} \mathrm{O}$. The largest chemical shift changes were observed for the $\mathrm{C} \alpha$ and $\mathrm{H} \alpha$ resonances of $\mathrm{Cys}{ }^{1} \cdot{ }^{13} \mathrm{C} \alpha$ chemical shifts of $\mathrm{Cys}^{1}$ and $\mathrm{Cys}^{6}$ were more shielded and $\mathrm{C} \alpha$ 's of $\mathrm{Tyr}^{2}$ and $\mathrm{Ile}^{3}$ were more deshielded in the presence of aspartate buffer. The ${ }^{13} \mathrm{C} \alpha$ chemical shifts of $\mathrm{Gln}^{4}, \mathrm{Asn}^{5}$, $\mathrm{Pro}^{7}$ and $\mathrm{Leu}^{8}$ were not affected by the presence of aspartate buffer. As shown by black bars in Fig. 5A, the H $\alpha$ 's of $\mathrm{Cys}^{1}$, Ile $^{3}$ and $\mathrm{Cys}^{6}$ were also affected. The strong effects of aspartate on the $\mathrm{C} \alpha$ and $\mathrm{H} \alpha$ chemical shifts of $\mathrm{Cys}^{1}$ could be due to an electrostatic interaction between the positive charge of the $\mathrm{N}$-terminus at $\mathrm{Cys}^{1}$ and the negative charge of the carboxylate group of the aspartate at $\mathrm{pH} 4.5$ In order to test this hypothesis, we recorded 2D ${ }^{13} \mathrm{C}-{ }^{1} \mathrm{H}$ HSQC of oxytocin in the presence and absence of aspartate buffer at $\mathrm{pH}$ 1.6. Highly similar chemical shifts were measured from the two spectra (see Supporting information). These results show that at a very low $\mathrm{pH}$, where the carboxylate groups of aspartate are protonated, there is no effect at $\mathrm{Cys}^{1}$. This observation confirms that at higher $\mathrm{pH}$, when most of the carboxylate groups of aspartate are deprotonated and thus negatively charged, there is indeed an electrostatic interaction between the aspartate and the N-terminus of Cys ${ }^{1}$.

\subsubsection{Influence of zinc ions on the conformation of oxytocin in water}

Fig. 5B shows that $\mathrm{C} \alpha$ and $\mathrm{H} \alpha$ chemical shifts of almost all amino acid residues of oxytocin are shifted in the presence of $\mathrm{Zn}^{2+}$. The largest chemical shift changes are observed for $\mathrm{C} \alpha$ of $\mathrm{Tyr}^{2}$. In $\mathrm{Tyr}^{2}, \mathrm{Gln}^{4}, \mathrm{Cys}^{6}$, Pro ${ }^{7}$, and Gly ${ }^{9}$ the $\mathrm{C} \alpha$ nuclei are more deshielded in the presence of $\mathrm{Zn}^{2+}$. In contrast, in $\mathrm{Ile}^{3}$ and $\mathrm{Asn}^{5}$ the $\mathrm{C} \alpha$ nuclei are more shielded in the presence of $\mathrm{Zn}^{2+}$. The presence of $\mathrm{Zn}^{2+}$ does not cause changes in the $\mathrm{C} \alpha$ and $\mathrm{H} \alpha$ chemical shifts of Leu $^{8}$. The largest $\Delta \delta$ is observed for the $\mathrm{H} \alpha$ of $\mathrm{Cys}^{1}$. Interestingly, similar to the effect observed for aspartate buffer on oxytocin, most chemical shift changes for $\mathrm{C} \alpha$ induced by $\mathrm{Zn}^{2+}$ are of opposite sign when compared to those for $\mathrm{H} \alpha$ of the same residue.

\subsubsection{Influence of divalent metal ions on oxytocin in aspartate buffer}

As shown in Fig. 5C, the effects of $\mathrm{Zn}^{2+}$ on the chemical shifts of oxytocin in aspartate are very similar to the effects observed in $\mathrm{D}_{2} \mathrm{O}$ (Fig. 4B), suggesting that a similar change is induced in both circumstances. A small chemical shift change was observed only in the $\mathrm{C} \alpha$ of $C y s^{1}$.

The effects of $\mathrm{Mg}^{2+}$ on the chemical shifts of $\mathrm{C} \alpha$ and $\mathrm{H} \alpha$ resonances of oxytocin in aspartate buffer are much smaller than those observed in the presence of $\mathrm{Zn}^{2+}$ ions. Although smaller, also in the case of $\mathrm{Mg}^{2+}$, the effects on $\mathrm{C} \alpha$ resonances are generally opposite to those seen for the $\mathrm{H} \alpha$ resonance of the same residue (Fig. 5D).

\section{4. ${ }^{3} J_{\mathrm{HNH} \alpha}$ coupling constants of OT in aspartate buffer in the absence and presence of metal ions}

To obtain information about ${ }^{3} \mathrm{~J}_{\mathrm{HNH} \alpha}$ coupling constants, $1 \mathrm{D}$ proton NMR spectra were recorded for OT in aspartate buffer in the absence and presence of $\mathrm{Zn}^{2+}$ and $\mathrm{Mg}^{2+}$. From the results displayed in Table 2, we have found that ${ }^{3} \mathrm{~J}_{\mathrm{HNH} \alpha}$ coupling constants of oxytocin in all conditions are relatively similar. 


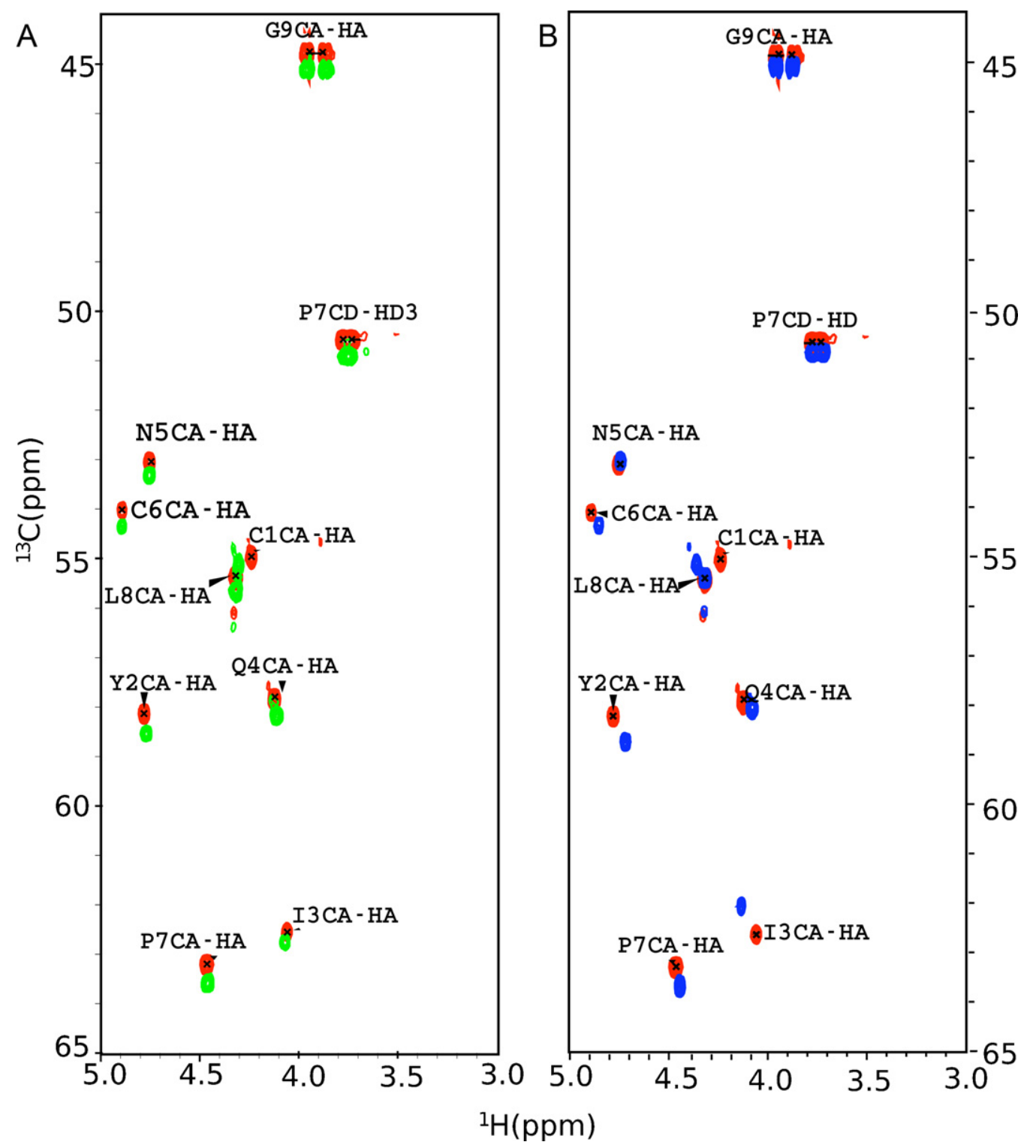

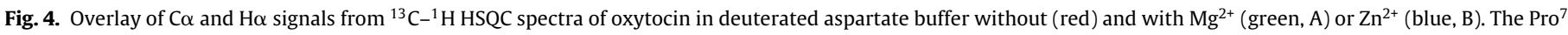
$\mathrm{C} \alpha-\mathrm{H} \alpha$ correlation is also shown in these spectra.

\section{Discussion}

Our study presents nearly complete NMR assignment of oxytocin in aspartate buffer in the presence and absence of divalent metal ions, $\mathrm{Zn}^{2+}$ and $\mathrm{Mg}^{2+}$. 2D ${ }^{1} \mathrm{H}-{ }^{1} \mathrm{H}$ NOESY spectra of oxytocin

Table 2

${ }^{3} \mathrm{~J} \mathrm{HnH} \alpha$ coupling constants of oxytocin in aspartate buffer in the absence and presence of divalent metal ions $(\mathrm{Hz})$.

\begin{tabular}{llll}
\hline Residue & $\begin{array}{l}\text { Oxytocin in } \\
\text { aspartate buffer }\end{array}$ & $\begin{array}{l}\text { Oxytocin and } \\
\mathrm{MgCl}_{2} \text { in aspartate } \\
\text { buffer }\end{array}$ & $\begin{array}{l}\text { Oxytocin and } \\
\mathrm{ZnCl}_{2} \text { in } \\
\text { aspartate buffer }\end{array}$ \\
\hline Y2 & 7.46 & 7.46 & 7.3 \\
L8 & 6.24 & 6.24 & 6.29 \\
G9 & 5.88 & 5.88 & 5.67 \\
N5 & 6.13 & 6.21 & 6.14 \\
Q4 & 8.05 & 8 & 8.04 \\
C6 & 3.71 & 3.99 & 3.47 \\
I3 & 6.4 & 6.27 & 6.12 \\
\hline
\end{tabular}

n.d: not determined. in aspartate buffer clearly demonstrate that the residue pairs $\mathrm{Ile}^{3}-\mathrm{Asn}^{5}$ and $\mathrm{Ile}^{3}-\mathrm{Cys}^{6}$ are in close proximity. These NOEs are also present in a $2 \mathrm{D}^{1} \mathrm{H}-{ }^{1} \mathrm{H}$ NOESY spectrum of oxytocin in water. Molecular dynamic studies by Wyttenbach et al. (Wyttenbach et al., 2008) suggest an interaction between $\mathrm{H} \alpha$ of $\mathrm{Tyr}^{2}$ and the Gly ${ }^{9}$ amide group of oxytocin in water, but we did not find evidence to support this interaction.

This study clearly shows that $\mathrm{Zn}^{2+}$ and aspartate buffer interact with oxytocin in solution at $\mathrm{pH} 4.5$. Aspartate buffer induces a minor change in the NMR spectrum oxytocin in $\mathrm{D}_{2} \mathrm{O}$ with the largest chemical shift changes are observed in Cys ${ }^{1}$. We suggest that there is an electrostatic interaction between the positively charged $\mathrm{N}$ terminus of $\mathrm{Cys}^{1}$ and the negatively charged carboxylate groups of aspartate. This hypothesis is supported by the fact that at $\mathrm{pH}$ 1.6, when the most carboxylate groups of aspartate are protonated, no changes in chemical shifts are found. $\mathrm{Zn}^{2+}$ induces strong and similar effects on oxytocin in aspartate buffer and in $\mathrm{D}_{2} \mathrm{O}$, suggesting that a similar change is induced in both circumstances. In our previous study (unpublished results), $\mathrm{Zn}^{2+}$ was shown to improve oxytocin stability only slightly in water, but much more in 

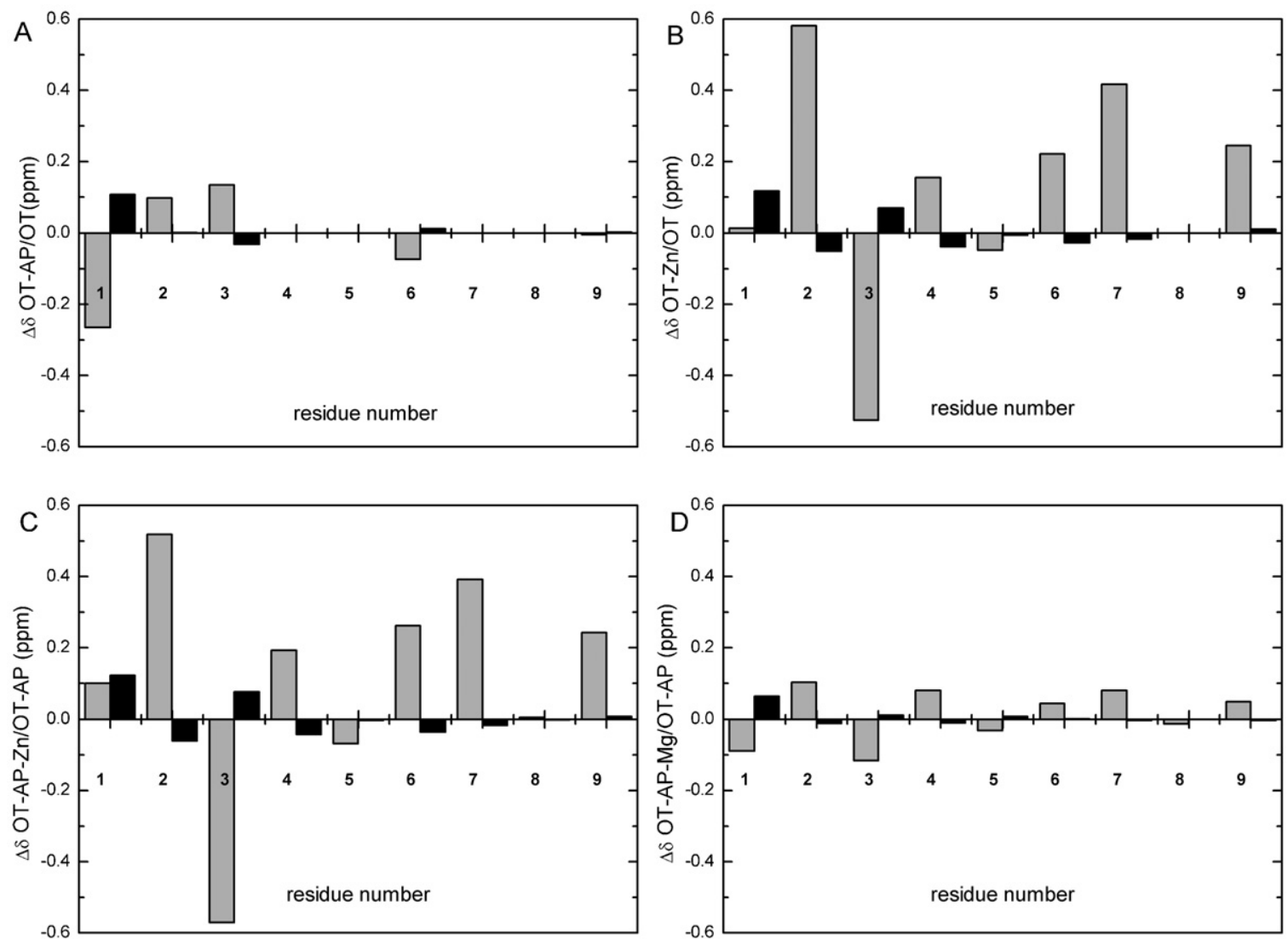

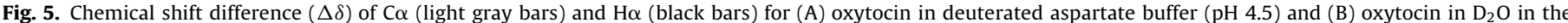

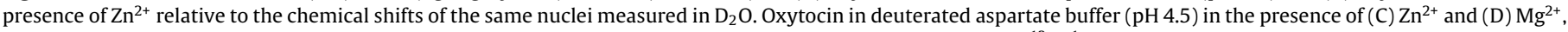
relative to the chemical shifts of the same spins measured in deuterated aspartate buffer pH 4.5 , analyzed by $2 \mathrm{D}{ }^{13} \mathrm{C}-{ }^{1} \mathrm{H}$ HSQC spectroscopy.

the presence of aspartate. The small effect of $\mathrm{Zn}^{2+}$ on the chemical shift of the $\mathrm{C} \alpha$ of $\mathrm{Cys}^{1}$, which was observed only in the presence of aspartate, may be relevant in this respect. We suggest that the negatively charged carboxylate groups of aspartate neutralize the positive charge of the $\mathrm{N}$-terminus of Cys ${ }^{1}$, allowing the interactions with $\mathrm{Zn}^{2+}$ to become more favorable. It is well-known that $\mathrm{Zn}^{2+}$ interact favorably and specifically with nitrogen lone pair donors in proteins, whereas $\mathrm{Ca}^{2+}$ and $\mathrm{Mg}^{2+}$ more generally bind oxygen atoms to complex carboxylates (Glusker et al., 1999). The arrangement of carbonyl/carboxyl groups around the $\mathrm{Zn}^{2+}$ might also play a role and may explain the observed chemical-shift changes and the protection of the disulfide bridge against intermolecular reactions that lead to dimerization. This result was confirmed experimentally from the degradation pattern of oxytocin in the presence of divalent metal ions measured by LC/MS(MS). It was found that divalent metal ions, particularly $\mathrm{Zn}^{2+}$, strongly reduced reactions of the cysteine groups leading to the formation of oxytocin dimers (unpublished result).

A modeling study of oxytocin-zinc complex by Liu et al. (2005) demonstrated the ability of $\mathrm{Zn}^{2+}$ to coordinate with oxytocin by which the structural conformation of oxytocin in a physiological environment was strongly affected. The observation of chemicalshift changes for the $\mathrm{C} \alpha$ and $\mathrm{H} \alpha$ resonances suggest that small changes in backbone dihedral angles may occur to accommodate $\mathrm{Zn}^{2+}$, although the effects may also arise from a direct influence on the chemical shifts through electric field effects. Drastic changes in the overall structure of the molecule can be ruled out, since the values of ${ }^{3} \mathrm{JHNH}_{\mathrm{HN}}$ coupling constants of the oxytocin in the absence and presence of metal ions are quite similar (Table 2) and no changes were observed in the pattern of NOEs upon addition of $\mathrm{Zn}^{2+}$ (Fig. 2).
Previous conformational studies of oxytocin by nuclear magnetic resonance (NMR) have been performed in phosphate buffer (Ohno et al., 2010). It was also studied the conformation of vasopressin and its derivates in aqueous solution (Trzepalka et al., 2004), the backbone conformation of the two related peptides is expected to be very similar.

Given the very similar coupling constants, increased propensities for the formation of canonical helical or extended secondary-structure elements are not likely, despite the observation of rather significant and anti-correlated changes in $\mathrm{C} \alpha$ and $\mathrm{H} \alpha$ chemical shifts (Wishart, 2011). Rather, the interaction with $\mathrm{Zn}^{2+}$ appears directly responsible for the observed spectral changes, which are most likely due to polarization changes of nearby chemical bonds. The effects of $\mathrm{Mg}^{2+}$ on the chemical shifts of $\mathrm{C} \alpha$ and $\mathrm{H} \alpha$ resonances of oxytocin in aspartate buffer are much smaller than those of $\mathrm{Zn}^{2+}$. This result is in agreement with our finding from ITC that $\mathrm{Mg}^{2+}$ show only very weak heat effects when added to solutions of oxytocin (unpublished results). The small chemicalshift changes in the backbone of residues Cys ${ }^{1}, \mathrm{Tyr}^{2}$ and $\mathrm{Ile}^{3}$ in the presence of $\mathrm{Mg}^{2+}$ in aspartate buffer may be due to a cation-pi interaction between $\mathrm{Mg}^{2+}$ and the aromatic side chain of $\mathrm{Tyr}^{2}$. However, the interactions between $\mathrm{Mg}^{2+}$ and oxytocin in aspartate buffer are too weak to cause protection against degradation. We have found that there were no changes in NOESY spectrum of oxytocin upon addition of $100 \mathrm{mM}$ of $\mathrm{Zn}^{2+}$. Also backbone ${ }^{3} \mathrm{~J}_{\mathrm{HNH} \alpha}$ couplings are very similar for all studied samples. It means that there are no such drastic changes in oxytocin structure. The only large changes observed are the differences in $\mathrm{C} \alpha-\mathrm{H} \alpha$ secondary chemical shifts, and these are attributed to a direct effect of zinc ions in the adduct. Moreover, binding of oxytocin-Zn complex in aspartate buffer is 
very weak, as shown by the small $K_{\mathrm{d}}$ values obtained from the ITC data $(0.16 \mathrm{mM})$.

\section{Conclusion}

In conclusion, our NMR studies reveal that $\mathrm{Zn}^{2+}$ significantly affects oxytocin in aqueous solution at the molecular level. $\mathrm{Zn}^{2+}$ causes changes in the chemical shifts of almost all residues of oxytocin while $\mathrm{Mg}^{2+}$ only induces very modest chemical-shift changes in some residues. In contrast, analysis of the NOESY spectra in the presence and absence of $\mathrm{Zn}^{2+}$ showed that the same NOEs are present under both circumstances, albeit with slightly altered intensities. The presence of a positive charged of $\mathrm{Zn}^{2+}$ per se will cause polarization of nearby chemical bonds and thus may explain the observed chemical shift changes. The differences in ligand coordination preferences of $\mathrm{Zn}^{2+}$ and $\mathrm{Mg}^{2+}$ are likely responsible for the observed differences, whereas the $\mathrm{pH}$-dependent stability may be related to the ability of aspartate buffer to assist this process.

\section{Acknowledgments}

This study was performed within the framework of the Dutch Top Institute Pharma, project number D6-202. The authors want to thank MSD Oss for providing oxytocin for the study and Ruud M. Scheek at the Faculty of Mathematics and Natural Sciences, Nijenborgh 4, 9747 AG Groningen, The Netherlands for helpful discussions.

\section{Appendix A. Supplementary data}

Supplementary data associated with this article can be found, in the online version, at http://dx.doi.org/10.1016/j.ijpharm. 2013.01.051.

\section{References}

Ananthanarayanan, V.S., Belciug, M.P., Zhorov, B.S., 1996. Interaction of oxytocin with $\mathrm{Ca}^{2+}$ : II. Proton magnetic resonance and molecular modeling studies of conformations of the hormone and its $\mathrm{Ca}^{2+}$ complex. Biopolymers 40 , 445-464.

Avanti, C., Amorij, J.P., Setyaningsih, D., Hawe, A., Jiskoot, W., Visser, J., Kedrov, A., Driessen, A.J., Hinrichs, W.L., Frijlink, H.W., 2011. A new strategy to stabilize oxytocin in aqueous solutions: I. The effects of divalent metal ions and citrate buffer. AAPS J. 13, 284-290.

Avanti, C., Permentier, H.P., Dam, A.V., Poole, R., Jiskoot, W., Frijlink, H.W., Hinrichs, W.L.J., 2012. A new strategy to stabilize oxytocin in aqueous solutions: II. Suppression of cysteine-mediated intermolecular reactions by a combination of divalent metal ions and citrate. Mol. Pharmaceutics 9, 554-562.

Boyd, J., Moore, G.R., Williams, G., 1984. Correlation of proton chemical shifts in proteins using two-dimensional exchange correlated spectroscopy. J. Magn. Reson. 58, 511-516.

Cavanagh, C., Fairbrother, W.J., Palmer, A.G., Skelton, N.J., 2006. Protein NMR spectroscopy. In: Principles and Practice, Second Edition.

Davis, D.G., Bax, A., 1985. Assignment of complex ${ }^{1} \mathrm{H}$ NMR spectra via twodimensional homonuclear hartman-hahn spectroscopy. J. Am. Chem. Soc. 107, 2820-2821.
Delaglio, F., Grzesiek, S., Vuister, G.W., Zhu, G., Pfeifer, J., Bax, A., 1995. NMR pipe a multidimensional spectral processing system based on unix pipes. J. Biomol. NMR 6, 277-293.

du Vigneaud, V., Ressler, C., Trippett, S., 1953. The sequence of amino acids in oxytocin, with a proposal for the structure of oxytocin. J. Biol. Chem. 205, 949-957.

Gard, J.W., Alexander, J.M., Bawdon, R.E., Albrecht, J.T., 2002. Oxytocin preparation stability in several common obstetric intravenous solutions. Am. J. Obstet. Gynecol. 186, 496-498.

Glickson, J.D., Rowan, R., Pitner, T.P., Dadok, J., Bothner-By, A.A., Walter, R., 1976. ${ }^{1} \mathrm{H}$ nuclear magnetic resonance double resonance study of oxytocin in aqueous solution. Biochemistry 15, 1111-1119.

Glusker, J.P., Katz, A.K., Bock, C.W., 1999. Metal ions in biological systems. Rigaku J. $16,8-19$.

Goddard, T.D., Kneller, D.G., 2003. SPARKY 3, University of California, San Francisco.

Hawe, A., Poole, R., Romeijn, S., Kasper, P., van der Heijden, R., Jiskoot, W., 2009. Towards heat-stable oxytocin formulations: analysis of degradation kinetics and identification of degradation products. Pharm. Res. 26, 1679-1688.

Hogerzeil, H.V., Walker, G.J.A., De Goeje, M.J., 1993. Stability of injectable ocytocics in tropical climates. World Health Organization, Geneva, WHO/DAP/93.6.

John, K.B., Plant, D., Hurd, R.E., 1992. Improved proton-detected heteronuclear correlation using gradient-enhanced $z$ and zz filters. J. Magn. Reson. A101, 113-117.

Johnson, L.F., Schwartz, I.L., Walter, R., 1969. Oxytocin and neurohypophyseal peptides spectral assignment and conformational analysis by $220 \mathrm{M} 1 \mathrm{~Hz}$ nuclear magnetic resonance. Proc. Natl. Acad. Sci. 64, 1269-1275.

Jurgens, P., Panteliadis, C., Fondalinski, G., 1982. Total parenteral nutrition of premature infants: metabolic effects of an exogenous supply of L-aspartic acid and L-glutamic acid. Z. Ernahrungswiss 21, 225-245.

Kay, L.E., Keifer, P., Saarinen, T., 1992. Pure absorption gradient enhanced heteronuclear single quantum spectroscopy with improved sensitivity. J. Am. Chem. Soc. 114, 10633-10635.

Liu, D., Seuthe, A.B., Ehrler, O.T., Zhang, X., Wyttenbach, T., Hsu, J.F., Bowers, M.T., 2005. Oxytocin-receptor binding: why divalent metals are essential. J. Am. Chem. Soc. 127, 2024-2025.

Markley, J.L., Bax, A., Arata, Y., Hilbers, C.W., Kaptein, R., Sykes, B.D., Wright, P.E., Wuthrich, K., 1998. Recommendations for the presentation of NMR structures of proteins and nucleic acids- IUPAC-IUBMB-IUPAB Inter-Union Task Group on the standardization of data bases of protein and nucleic acid structures determined by NMR spectroscopy. Eur. J. Biochem. 256, 1-15.

Maughan, K.L., Heim, S.W., Galazka, S.S., 2006. Preventing postpartum hemorrhage: managing the third stage of labor. Am. Fam. Physician 73, 1025-1028.

Mulder, F.A., Otten, R., Scheek, R.M., 2011. Origin and removal of mixed-phase artifacts in gradient sensitivity enhanced heteronuclear single quantum correlation spectra. J. Biomol. NMR 51, 199-207.

Ohno, A., Kawasaki, N., Fukuhara, K., Okuda, H., Yamaguchi, T., 2010. Complete NMR analysis of oxytocin in phosphate buffer. Magn. Reson. Chem. 48, 168-172.

Rholam, M., Cohen, P., Brakch, N., Paolillo, L., Scatturin, A., Di Bello, C., 1990. Evidence for beta-turn structure in model peptides reproducing proocytocin/neurophysin proteolytic processing site. Biochem. Biophys. Res. Commun. 168, 1066-1073.

Sikorska, E., Rodziewicz-Motowidlo, S., 2008. Conformational studies of vasopressin and mesotocin using NMR spectroscopy and molecular modelling methods. Part I: Studies in water. J. Pept. Sci. 14, 76-84.

Sikorska, E., Slusarz, M.J., Lammek, B., 2006. Conformational studies of vasopressin analogues modified with $\mathrm{N}$-methylphenylalanine enantiomers in dimethyl sulfoxide solution. Biopolymers 82, 603-614.

Smith, I.C., Deslauriers, R., Saito, H., Walter, R., Garrigou-Lagrange, C., McGregor, H., Sarantakis, D., 1973. Carbon-13 NMR studies of peptide hormones and their components. Ann. N.Y. Acad. Sci. 222, 597-627.

Trzepalka, E., Oleszczuk, M., Maciejczyk, M., Lammek, B., 2004. Solution structure of conformationally restricted vasopressin analogues. Acta Biochim. Pol. 51, 33-49.

Trissel, L.A., Zhang, Y., Douglass, K., Kastango, E., 2006. Extended Stability 425 of oxytocin in common infusion solution. Int. J. Pharmaceut. Compounding 10 , 156-158.

Wishart, D.S., 2011. Interpreting protein chemical shift data. Prog. Nucl. Magn. Reson. Spectrosc. 58, 62-87.

Wyttenbach, T., Liu, D., Bowers, M.T., 2008. Interactions of the hormone oxytocin with divalent metal ions. J. Am. Chem. Soc. 130, 5993-6000. 